\title{
The Relationship Between Nomophobia and Poorer Sleep Among College Students
}

\author{
Ellena Aurielle Kurnia ${ }^{1}$ Monty P. Satiadarma ${ }^{1}$ Linda Wati ${ }^{1 *}$ \\ ${ }^{1}$ Faculty of Psychology Universitas Tarumanagara, West Jakarta, 11440, Indonesia \\ "Corresponding author. Email: lindaw@fpsi.untar.ac.id
}

\begin{abstract}
As time goes by and communication technology is increasingly developing, there is an adverse effects if it is used inappropriately. Nomophobia is one of the psychological problems associated with the exclusive use or mobile phones so that they feel fear and anxiety when they are far from mobile phones. Then the definition of poorer sleep according to the International Classification of Sleep Disorders is a limited sleep pattern that has least three months for most days of the week along with complaints of daytime sleepiness. This study aims to examine the relationship between nomophobia and poorer sleep in college students. This study involved 292 college students from university in Indonesia consisting of 229 female participants and 63 male participants. The measuring instrument used in the Nomophobia Questionnaire by Yildirim \& Correia in 2015 and The Pittsburgh Quality of Sleep by Buysse et al., in 1988. The result of the data analysis of participants used the Spearman Correlation technique between nomophobia and poorer sleep, obtaining r (292) $=0.145$ and $p$-value $=0.013$. The correlation between these two variables shows that there is a positive and significant correlation between nomophobia and poorer sleep.
\end{abstract}

Keywords: Nomophobia, poorer sleep, college students, PSQI, sleep quality

\section{INTRODUCTION}

In the current era of globalization, humans are very dependent on technology, especially in communication systems. Most people welcomed the development of technology in the era of globalization, although not a few also had difficulties with increasingly sophisticated technological developments [32]. One of the technologies in the communication system that is developing rapidly is mobile phone or commonly known as a cellular telephone. Today mobile phone provide tremendous opportunities and convenience for users and at the same time, a mobile phone provide facilities that can help users complete their tasks, and make communication between individuals much easier [8]. If in the past the owners of mobile phone or television may be relatively limited to those who have sufficient purchasing power, but nowadays almost everyone has a mobile phone. There are even individuals has more than one mobile phones. This is evidenced in Majumder research [25], which is that based on data from the global mobile market, customers using mobile phone has increased to three million in 2018.

In the communication process, a mobile phone or cellular telephone is a facility needed by all groups, from children to the elderly. One of the most dominant mobile phone users from these circle is students. Today's mobile phone have become important part of technology culture, especially among teenage students, where the main need is to socialize, join other friends, and to be like [29]. Mobile phone are not only about sharing data, chatting, take a photos, but also provide other interesting features such as social media, games, and other applications [13]. It was reported that the rate of mobile phone use was higher among adolescents aged 18-24 and 68\% between ages 25-34 [14]. As time goes by, the need for communication may be felt to be higher and the distribution of information has also become faster. Even though the advantages of technology are growing, the use of technology, especially mobile phone can be present unfavorable risks. This is because it can cause several risks, namely individuals become stressed, less focused on things around them, individuals are more concerned with interactions in cyberspace, and insomnia [28]. Some people become so dependent on their mobile phones which is a sign of behavioral addiction which can lead to isolation, feelings of loneliness, decreased interpersonal relationships, and social interactions [4]. The impact of not being able to reach mobile phones, not only affects social relationships with other people, but also affects psychological health [1]. One of the health problems is nomophobia (no mobile phones phobia). Nomophobia is a new pathology that might be categorized as a clinical disorder [8].

According to King et al., [4] nomophobia is a feeling of discomfort or anxiety in someone when they are far away or cannot reach their mobile phones. According to Mahendra et al., and Mayangsari [11] the number of individuals suffering from nomophobia in Indonesia has increased significantly starting in 2013 , namely $75 \%$ with an age range of $18-24$ years and increased to $84 \%$ in 2014 
with a range ages $19-24$ years. This is also supported by a survey conducted in England in 2012, researchers found that $66 \%$ of 1000 participants developed feelings of fear when they lost or could not reach their mobile phones [21]. Nomophobia itself can be associated with individual dependence on mobile phones. Dependence on mobile phones can affect both physical and psychological aspects of the individual [31]. Individuals feel anxious if other people have difficulty contacting them, feel anxious when there is information and it turns out that they don't know, and feel anxious because they don't get the latest information (Y. Suprapto, personal communication, 2021, January 20).

Every individual needs sufficient sleep time to be able to carry out activities properly so that the need for adequate sleep is not only determined by the sleep time factor (sleep quantity), but also determined by the quality of sleep [15]. A person can be said to have a good sleep quality if they do not show signs of lack of sleep and do not have other problems in sleeping [20]. Most experts or professionals advise students to sleep 9 hours per night or an average of 7 to 8 hours per night [37]. There were $25 \%$ of students who reported having slept less than 6.5 hours per night [19]. Poorer sleep is a common problem that affects about $25 \%$ $40 \%$ of adolescent development [6]. One non-profit organization, the National Sleep Foundation, released the Annual Sleep in America Poll in 2011 which was conducted to see the effects of using electronic media before bedtime [26]. The results of a survey conducted by National Sleep Foundation in 2011 showed that $95 \%$ of the total respondents, aged 13-64 years, use electronic devices before bed and $43 \%$ of respondents complain that respondents rarely or even never get a satisfying sleep time [26]. Poorer sleep also has a serious impact on cognitive performance, emotional function, and if sleep disturbances to a chronic stage can cause a person to develop mood disorders [23]. The most influential psychological impact caused by lack of sleep is depression. Lack of prolonged sleep will make the sleep quality of the individual worse. According to the American College Health Association and the National College Health Assessment [37], individuals with depression and anxiety often experience a decrease in their sleep quantity due to symptoms of insomnia or the inability to sleep and wake up earlier.

Based on the description above, researcher is interested in knowing the relationship between nomophobia and poorer sleep in college students. The researcher wants to take a case about nomophobia because in addition to problems with academic demands, work, personal problems, and other problems that have been described above, there are factors of nomophobia which also have an impact on the lack of sleep for students. This is supported by the phenomena and findings from previous studies, that nomophobia has an influence on the lack of sleep in students. In addition, the effects that occur in students are that they feel excessive sleepiness during the day and unhealthy sleep habits due to the use of mobile phones at night. This study aims to provide education about nomophobia and increase public awareness in controlling the use of mobile phones so that feelings of anxiety that arise when they cannot access mobile phones can also be controlled to avoid other problems, especially lack of sleep for students.

\subsection{Our Contribution}

The results of this research are expected to be useful in the development of psychological science, in the fields of technology and communication, medical science, and social psychology. This research can be an illustration for students about the impact of nomophobia and poorer sleep which affect student life, both physically, cognitively, and socially. The results are expected to provide knowledge for readers in all circles, especially adolescents and early adults so that they can add insight and education about the impact of excessive cell phones use and the impact of lack of sleep. For the community, it is hoped that they can find out the effects or side effects of excessive cell phones use. So that in the future people will be wiser in using mobile phones and can understand the actions or behavior of using mobile phones so that individuals do not become increasingly nomophobic.

\subsection{Paper Structure}

The rest of the paper is organized as follows. Section 2 introduces the preliminaries used in this paper, which include nomophobia, poorer sleep, and college students. Section 3 background the related research and correlation each variable. Then, the demographic data of participants, procedure, research instrument (Nomophobia Questionnaire and Pittsburgh Quality of Sleep), result variable nomophobia and poorer sleep, additional data analysis were in Section 4. Section 5 was the findings and discussion about this research. Finally, Section 6 concludes the paper.

\section{BACKGROUND}

\subsection{Nomophobia}

\subsubsection{Definitions of nomophobia}

Nomophobia or no mobile phone phobia is one of the psychological problems associated with using cell phones exclusively so that you feel fear and anxiety if you are far from mobile phone [33]. Nomophobia refers to feelings of discomfort, anxiety, nervousness or sadness cause by the inability to use mobile phone [30]. Meanwhile, nomophobia is a specific phobia which is defined as discomfort or anxiety caused by the unavailability of mobile phone, personal computer (PC), or other virtual communication devices [7]. Another definition of nomophobia is described as an irrational fear when someone cannot reach their mobile phone, so they cannot communicate via their mobile phone [10]. From the explanation above, the researchers conclude that nomophobia is a feeling of anxiety, 
discomfort, and fear that arises in individuals when individuals cannot reach or access their mobile phone so they cannot communicate with other people.

\subsubsection{Dimensions of nomophobia}

There are four dimensions of nomophobia [9]. The first dimension is not being able to communicate. This refers to feelings of loss or difficulties contacting and being contacted by other people because of not being able to use instant communication service [9]. Furthermore, the second dimension is losing connectedness which refers to the feeling of losing connectivity provided by mobile phone, so they are cut off from online identities, especially social media [9]. The third dimension is not being able to access information. This third dimension refers to the feeling of discomfort when losing access to seek or retrieve information that is spread through social networks on the mobile phone [9].

The last dimension, giving up convenience, is a feeling of discomfort when individuals cannot use their mobile phone or a feeling of comfort when the individual remains near their mobile phone.

\subsubsection{Factors affecting nomophobia}

There are factors that cause nomophobia such as human needs in modern times, mobile phone are becoming a tool that makes human work easier, more social media is developing, changing the way communication between users becomes more effective [11]. Other factors that influence nomophobia were also expressed by Bianci and Philip [33], namely based on gender where men will have a more positive attitude in using electronics, self-esteem, age which shows that parents are less likely than young people.

\subsection{Poorer Sleep}

\subsubsection{Definitions of poorer sleep}

Sleep is an altered state of consciousness which constitutes nearly a third of the hour in human life (Farooq et al., 2019). The need for sleep of a good individual is not only determined by the quantity of sleep, but the connection between the brain and the body in practical terms and motor activity stops [15]. A person can be said to have a healthy or normal sleep pattern characterized by sufficient sleep time or duration, sleeping at the right time, regular sleep time, good sleep quality, and without any sleep disturbances [17]. Based on the definition according to the International Classification of Sleep Disorders (ICSD-3) sleep deprivation or poorer sleep is a limited sleep pattern that has lasted at least three months for most days of the week along with complaints of daytime sleepiness [33].

\subsubsection{Symptoms of poorer sleep}

According to the Ministry of Health of The Republic of Indonesia [35], adolescence to adulthood in the 18-40 year range requires 7 hours of sleep at night. Symptoms of poorer sleep include feeling sleepy during the day, mood swings (irritability, feeling depressed), forgetfulness, and difficulties learning new concepts, inability to concentrate or focus on tasks, and weight gain [2]. In addition, other symptoms of poorer sleep are divided into two, physical symptoms that we can see such as dark areas around the eyes, swelling of the eyelids, excessive drowsiness, blurred vision, dizziness, and psychological symptoms such as apathy, laziness to speak, unable to concentrate, and hallucinations [5]

\subsubsection{Impact of poorer sleep}

Each individual has a different amount of sleep. Some individuals put aside sleep time by doing various things or for various reasons. There are short-term consequences of poorer sleep such as decreased quality of life, emotional distress, mental health problems, and behavioral problems in individuals [17]. Poorer sleep can also cause psychological and physical disorders such as loss of energy, mood swings, and the inability to concentrate on studying [25]. The impact of poorer sleep on adolescents has an effect on psychosocial health, school performance, and the most severe impact is the use of nicotine and marijuana [17].

\section{METHODS}

\subsection{Participants and Procedure}

A total of 292 college students were voluntary participating in the study include 63 males, 229 females. Based on the age category, the study participants ranging from 18-24 years old. The study participants consisted of students of semesters 1, 3, 4, 5, 6, 7, 8, 9, 10, and 11. Faculty involved in the research consisted of the faculty of economics and business, law, communication, medicine, psychology, arts and design, engineering, pharmacy, hospitality and tourism, and faculty of agriculture. The researcher used nonprobability sampling convenience type to asking participants to fill out an electronic questionnaire using google form.

\subsection{Participants and Methods}

The research design used in this research is quantitative research with a non-experimental form. Quantitative research is a method used by researchers to test certain theories and is associated with research variables and is useful for testing hypotheses in order to obtain significant results between predetermined variables. The form of nonexperimental research was used in this study because researchers only measured two variables related to 
individuals without giving treatment. The sampling technique used in this study is convenience sampling which is included in the non-probability sampling category. The choice of convenience sampling technique is because the researcher can take a sample of anyone the researcher meets with the conditions that the participants meet the criteria for study participants.

The questionnaire was made in the form of a google form due to the COVID-19 pandemic so that it was not possible for researchers to be able to distribute data offline. Questionnaires were distributed from November 10, 2020 to December 10, 2020. After the data had been collected, the researcher then transferred the data to the SPSS program to start the data processing. Data that will be entered, processed and analyzed are demographic data and answers from participants.

\subsection{Research Instrument}

Nomophobia Questionnaire (NMP-Q) is a nomophobia measuring instrument developed by Yildirim and Correia in 2015 [22]. NMP-Q consists of 20 items that fall into 4 dimensions, that is not being able to communicate, losing connectedness, not being able to access information, and giving up convenience [22]. NMP-Q is answered by using a scale of 1 (strongly disagree) to 7 (strongly agree).

Pittsburgh Sleep Quality Index (PSQI) is a poorer sleep measuring instrument developed by Buysse et al., in 1988 [12]. PSQI is a measure of quality and efficient sleep patterns because it assesses sleep quality on seven components, namely subjective sleep quality, sleep latency, sleep duration, habitual sleep efficiency, sleep disturbances, use of sleeping medication, and daytime dysfunction [16]. The PSQI consists of 19 questions that are grouped into seven component scores and each of them is equally weighted on a scale of 0-3 [12]. The total score of the seven components ranges from $0-21$, if the score is higher than the range $0-21$, it indicates a worse sleep quality [12].

\subsection{Research Results}

Participants gender in this study, the number of female participants was $\mathrm{n}=292(78.4 \%)$ was more dominant than male was $\mathrm{n}=63(21.6 \%)$. The participant age more dominant was 21 years old $(\mathrm{n}=95,32.5 \%)$. College students that participate in this study mostly from the seventh semester $(\mathrm{n}=106,36.3 \%)$ and mostly from faculty of psychology $(\mathrm{n}=72,24.7 \%)$.

Researcher conducted normality tests to determine the right correlation techniques for use in this study. Base on normality test results using One-Sample KolmogorovSmirnov. Data distribution on nomophobia variable is not distributed normally with values $(p=.002<0.05)$. Then data distribution on poorer sleep variable is not distributed normally with values $(p=0.000<0.05)$. Based on these results, it is known that the significance value is less that 0.05 which means that the data is not distributed normally. The results based on correlation test results using Spearman's Correlation analysis technique, it was obtained that the nomophobia variable has a positive relationship and significant with poorer sleep variable. The results of data analysis with Spearman correlation technique, shows from the value $r(292)=0.145)$ and the value $p=0.013<0.05$. The result of the correlation test of the nomophobia and poorer sleep variables can be seen in detail and clearly in Table 1.

Researchers also tested the correlation between the nomophobia variable and the component of poorer sleep. The result of the correlation test between nomophobia and sleep quality component obtained the value $\mathrm{r}(292)=0.139$ dan $p=0.017<0.05$. There is a significant and positive relationship between the nomophobia variable and the sleep quality component. This means that if someone is getting more nomophobic, the sleep quality of the participants will get worse. Next, the correlation test result between nomophobia variable and sleep latency component obtained the value $\mathrm{r}(292)=0.073$ and $p=0.212>0.05$. This shows that there is an insignificant and positive relationship between the nomophobia variable and the sleep latency component. The correlation test result between nomophobia variable with sleep duration component obtained the value $\mathrm{r}(292)=0.045$ dan $p=0.443>0.05$. This shows that there is an insignificant and positive relationship between the nomophobia variable and the sleep duration component. Next, the correlation test result between nomophobia variable with habitual sleep efficiency component obtained the value $r(292)=0.027$ dan $p=0.648>0.05$. This shows that there is an insignificant and positive relationship between the nomophobia variable and the habitual sleep efficiency component.

The correlation test result between nomophobia variable with sleep disturbance component obtained the value $r$ $(292)=0.190$ dan $p=0.001<0.05$. This shows that there is an significant and positive relationship between the nomophobia variable and the sleep disturbance component. Next, the correlation between nomophobia variable with use of sleeping medication component obtained the value $r$ $(292)=0.077$ dan $p=0.192>0.05$. This shows that there is an insignificant and positive relationship between the nomophobia variable and the use of sleeping medication component. Last one, the correlation between nomophobia variable with daytime dysfunction component obtained the value $r(292)=0.040$ dan $p=0.496>0.05$. This shows that there is an insignificant and positive relationship between the nomophobia variable and the daytime dysfunction component.

The next step was for the researcher to test the correlation between poorer sleep and nomophobia dimensions. The results of the correlation between poorer sleep and not being able to communicate dimensions obtained the values $r$ (292) $=0.124$ and $p=0.034<0.05$. This indicate that there is a significant and positive relationships between poorer sleep and not being able to communicate dimensions. Next, the correlation between poorer sleep and losing connectedness dimensions obtained the values $\mathrm{r}(292)=0.175$ and $p=$ $0.003<0.05$. This indicate that there is a significant and positive relationships between poorer sleep and losing connectedness dimensions. The correlation between poorer sleep and not being able to access information dimensions 
obtained the values $\mathrm{r}(292)=0.065$ and $p=0.265>0.05$. This shows that there is an insignificant and positive relationship between the poorer sleep variable and the not being able to access information dimension. Last, the correlation between poorer sleep and giving up convenience dimension obtained the values $\mathrm{r}(292)=0.103$ and $p=0.080$ $>0.05$. This shows that there is an insignificant and positive relationship between the poorer sleep variable and the giving up convenience dimension.

\subsection{Additional Data Analysis}

The researcher conducted different tests as additional data that aims to complement the results of the study based on demographic data participants, such as gender and semester. Gender analysis method using Kruskal-Wallis Test. The results of the different test for the nomophobia variable in terms of the gender of the participants, have a mean rank for men is 136.36 and a mean rank for women 149.29. Then the value of $\mathrm{H}=1.159$ and $p=0.282$, this shows that the $p$ result is greater than 0.05 so that there is no significant difference between the nomophobia variable based on the gender of the participants. Next, The results of the different test for the poorer sleep variable in terms of the gender of the participants, have a mean rank for men is 132.21 and a mean rank for women 150.43. Then the value of $\mathrm{H}=2.332$ and $p$ $=0.127$, this shows that the $p$ result is greater than 0.05 so that there is no significant difference between the poorer sleep variable based on the gender of the participants.

Researchers also performed a difference test between the poorer sleep variable in terms of semester using the
Kruskall-Wallis Test. The results of the difference test between the poorer sleep variable in terms of the participant's semester showed the mean rank value in semester 1 was 132.19 , the mean rank value in semester 3 was 149.75 , the mean rank value in semester 4 was 241.33 . Then in semester 5 it has a mean rank value of 176.46, the mean rank value in semester 6 is 78.50 , the mean rank value in semester 7 is 133.49 , the mean rank value in semester 8 is 95.25 , the mean rank value in semester 9 is 185.43 , the mean rank value is semester 10175.38 , and finally the mean rank value in semester 10 is 79.00 . The value of $\mathrm{H}=25.142$ and the value of $p=0.003$ where the $p$ value is less than 0.05 , which means that there is a significant relationship between the poorer sleep variable in terms of the participant semester.

The results of the different test for the nomophobia variable in terms of the participant's semester showed the mean rank value in semester 1 was 127.88 , the mean rank value in semester 2 was 148.61 , the mean rank value in semester 4 was 110.00 , the mean rank value in semester 5 was 153.90 , the mean rank value in semester 6 , namely 47.17 , the mean rank value in semester 7 was 159.78 , the mean rank value in semester 8 was 116.69 , the mean rank value in semester 9 was 88.43, the mean rank value in semester 10 was 112.88 , and finally the mean rank value in semester 9 was 112.88. 11th semester which is 232.50 . The value of $\mathrm{H}=$ 17.491 and the value of $p=0.042$ where the $p$ value is less than 0.05 , which means that there is a significant relationship between the nomophobia variable in terms of the participant semester.

Table 1 Hypothesis test results for the correlation of nomophobia and poorer sleep variables

\begin{tabular}{cc}
\hline $\mathrm{R}$ & Nomophobia and Poorer Sleep \\
\hline$p$ & 0.145 \\
& 0.013 \\
\hline
\end{tabular}

\section{FINDINGS AND DISCUSSIONS}

Based on the results of research on the relationship between nomophobia and poorer sleep in college students, it was found that the two variables had a significant and positive relationship. Thus, if the value of the nomophobia variable is higher, the value of the poorer sleep variable will also be high. Conversely, if the value of the nomophobic variable value gets lower, the poorer sleep variable value will also be lower. There are several things that affect the relationship between the nomophobia and poorer sleep variables in students, such as the lack of additional data, namely the time to use mobile phones in a day and activities carried out by participants in using mobile phones. The results in this study need to be reexamined to be sure, because of the weaknesses in the study that might affect the research results.

The significant relationship between nomophobia and poorer sleep indicates that if individuals use excessive mobile phones for fear of appearing anxious or unable to reach or use their mobile phones, the individual will experience sleep deprivation or lack of sleep. The results of the study are in accordance with research conducted by Farooq et al., [25] that excessive use of mobile phones can provide poor sleep quality and sleep disturbances.

Most of the students who participated in this study were 229 women. This shows that the majority of cell phones users who are excessive and also experience lack of sleep or poorer sleep are female. Women are more at risk for addiction to cell phones use than men because women use relatively more features and applications on mobile phones [18]. There is another study explained that the level of spending time on mobile phones on men is more than women [24]. Based on the evidence presented, the differences that occur between men and women are influenced by the style of telephones usage of each individual. Women are allegedly using cameras in their mobile phones more often and communicating with their 
surroundings to strengthen social interactions, while men use mobile phones only to access applications as needed [27].

The researcher also tested the nomophobia and poorer sleep variables in terms of gender. Based on the results of these tests, it was found that there was no significant difference in the nomophobia and poorer sleep variables in terms of gender. This means that the nomophobia variable is not influenced by gender. This is supported by the other research that in this study there was no difference between women and men excessive use of cell phones because cell phones use was universal and also distributed evenly among college student [3]. In addition to testing the difference between the nomophobia and poorer sleep variables in terms of gender, the researcher also conducted a difference test between the nomophobia and poorer sleep variables in terms of the participant semester. The result of the difference test for the nomophobia variable in terms of the semester has a value of $\mathrm{H}=17.491$ and a significance of $0.042<0.05$. This shows that the nomophobia variable in terms of the participant's semester has a relationship. The results of the different test for the poorer sleep variable in terms of the participant semester have a value of $\mathrm{H}=25.142$ and a significance of $0.003<0.05$. This shows that there is a significant relationship between the poorer sleep variable in terms of the participant semester. In the two tests carried out between the nomophobia and poorer sleep variables in terms of the participant semester, the results showed that there was a significant relationship between the nomophobia and poorer sleep variables in terms of the participant semester. This means that the semester or level of education being taken affects the score or level of nomophobia and poorer sleep. The results of this difference test are in accordance with the results of tests conducted in the research of Daei et al., [4] that nomophobia has a significant relationship with gender, age group, and education level. This means that gender, age group, and level of education affect the high and low scores of nomophobia.

From the research that has been carried out, the researcher realizes that this research still has many limitations and shortcomings, both in the discussion, incomplete theoretical studies, and the results of data processing that may not be perfect. In addition, in the data collection process, researchers experienced limitations and difficulties due to policies imposed by the government in order to cut the spread of COVID-19 so that there were not too many participants. In addition, there are several limitations that can be corrected in future studies, namely first, the participants in this study did not balance the number of male and female partitions. Second, because of the lack of demographic data that was not included such as the duration of cell phone use in a day, how long have participants used cell phones, asked about the use of cell phones owned by participants, and activities carried out by participants when using cell phones, resulting in a lack of analysis. additional data that can be used in this study. This can affect the results of the study. In addition, with the online data dissemination process, it would be difficult for researchers to ascertain whether the participants understood the contents of the questionnaire and the question items and so that the participants who filled out the questionnaire matched the criteria required by the researcher.

\section{CONCLUSIONS}

Based on the results of research on nomophobia and poorer sleep among college students, the final result is there is a significant positive correlation. Thus, if the value of the nomophobia increases, then the value of the poorer sleep will also increase. If the value of the nomophobia decreases, then the value of the poorer sleep will also decreases.

\section{ACKNOWLEDGMENT}

The First author would like to thank Mr. Monty P. Satiadarma and Ms. Linda Wati as the second and third author and lecturer. The researcher also thanks participants from the university in Indonesia. Also, thanks to Universitas Tarumanagara especially the Faculty of Psychology that gives an opportunity for researchers. This research is also supporting for my bachelor graduation.

\section{REFERENCES}

[1] A. Aziz, "No mobile phone phobia di kalangan mahasiswa pasca sarjana", Jurnal Bimbingan dan Konseling, vol. 6, no. 1, 2019, pp. 1-10.

[2] A. Bandyopadhyay, N. L. Sigua. What is sleep deprivation? Am J Respir Crit Care Med, 199, 2019, pp. $11-12$.

[3] A. Bianchi, J. G. Phillips, Psychological predictors of problem mobile use, in: Pavithra, S. Madhukumar, M. Murthy. A study on nomophobia-mobile phones dependence, among students of medical college in bangalore. National Journal of Community Medicine, 6(2), 2015, pp. 340-344.

[4] A. Daei, H. Ashrafi-rizi, M. R. Soleymani, "Nomophobia and health hazards: Smartphone use and addiction among university students", International Journal of Preventive Medicine, vol. 10, no. 202, 2019.

[5] A. Hidayat, Pengantar Ilmu Keperawatan, in: R. D. Sanjaya, Hubungan antara kualitas tidur dengan kecenderungan berperilaku agresif pada remaja, Thesis, Universitas Sanata Dharma Yogyakarta, 2011. 
[6] A. L. Gamble (Eds.), "Adolescent sleep patterns and night-time technology use: Results of the Australian broadcasting corporation's big survey", Plos One, vol. 9, no. 11, 2014, e111700. DOI: 10.1371/journal.pone. 0111700 .

[7] A. L. S. King et al., Nomophobia: Impact of cell phone use interfering with symptoms and emotions of individuals with panic disorder compared with a control group, in: D. Tran, Classifying nomophobia as smartphone addiction disorder, UC Merced Undergraduate Research Journal, 9(1), 2016, pp. 1-22.

[8] A. M. R. Garcia, A. J. M. Guerrero, J. L. Belmonte, "Nomophobia: An individual's growing fear of being without a smartphone - a systematic literature review", International Journal Environmental Research and Public Health, vol. 17, 2020, pp. 1-19. DOI: 10.3390/ ijerph17020580.

[9] C. Yildirim, A. P. Correia, Exploring the dimensions of nomophobia: Development and validation of a selfreported questionnaire, Journal Computers in Human Behaviour, 49, 2015, pp. 130-137. DOI: http://dx.doi. org/10.1016/j.chb.2015.02.059.

[10] C. Yildirim, A. P. Correia, Exploring the dimensions of nomophobia: Development and validation of a self-reported questionnaire, in: D. M. Gezgin, O. Cakir, Analysis of nomofobic behaviours of adolescents regarding various factors, Journal of Human Sciences, 13(2), 2016, pp. 2504-2519.

[11] D.C. Rahayuningrum, A. N. Sary, "Studi tingkat kecemasan remaja terhadap no mobile phone (nomophobia)", Jurnal Keperawatan BSI, vol. 7, no. 1, 2019, pp. 49-55.

[12] D. J. Buysse et al., "The Pittsburgh sleep quality index: A new instrument for psychiatric practice and research", Psychiatry Research, vol. 28, 1988, pp. 193213.

[13] D. Kagoya, "The impact of the use of cellphones on the community (study on the community of penguin village, gamelia district, lanny jaya regency, papua)", Acta Diurna Journal, vol. 4, no. 4, 2015.

[14] D. M. Gezgin, O. Cakir, "Analysis of nomofobic behaviors of adolescents regarding various factors", Journal of Human Sciences, 13(2), 2016, pp. 2504-2519.

[15] E. Lanywati, Insomnia, gangguan sulit tidur, in: $H$. Nilifda, Nadjmir, Hardisman, Hubungan kualitas tidur dengan prestasi akademik mahasiswa program studi pendidikan dokter Angkatan 2010 FK universitas andalas, Jurnal Kesehatan Andalas, 5(1), 2016, pp. 243249.

[16] G. Maheswari, F. Shaukat, "Impact of poor sleep quality on the academic performance of medical students". Cureus, vol. 11, no. 4, 2019, pp. 1-6. DOI:10.7759/cureus.4357.

[17] G. Medic, M. Wille, M. EH. Hemels, Short-and long-term health consequences of sleep disruption, Nature and Science of Sleep, 9, 2017, pp. 151-161.

[18] G. R. Park, G. W. Moon, D. H. Yang. The moderation effect of smartphone addiction in relationship between self-leadership and innovate behavior, in: S. Hidayat, Mustikasari, Kecanduan penggunaan smartphone dan kualitas tidur pada mahasiswa rik ui, 2014

[19] H. G. Lund, B. D. Reider, A. B. Whiting, J. R. Prichard, Sleep patterns and predictors of disturbed sleep in large population of college students, in: S. K. Adams, T. S. Kisler, Sleep quality as a mediator between technology-related sleep quality, depression, and anxiety, 16(1), 2013, pp. 25-30. DOI: 10.1089/ cyber.2012.0157.

[20] H. Nilifda, Nadjmir, Hardisman, "Hubungan kualitas tidur dengan prestasi akademik mahasiswa program studi pendidikan dokter angkatan 2010 FK universitas andalas", Jurnal Kesehatan Andalas, 5(1), 2016, pp. 243-249.

[21] I. A. Farooqui, P. Pore, J. Gothankar, "Nomophobia: An emerging issue in medical institutions?", Journal or Mental Health, 2017. DOI: 10.1080/09638237.2017. 1417564.

[22] I. B. Rangka et al., "Measuring psychometric properties of the Indonesian version of the nomophobia questionnaire (NMPQ): Insight from rasch measurement tool", Journal of Physics Conference Series 1114, 2018, pp. 1-7. DOI: 10.1088/1742-6596/1114/1/012127.

[23] J. Kamphuis et al., "Poor sleep as a potential causal factor in aggression and violence", Sleep Medicine, vol. 13, 2012, pp. 327-334.

[24] J. Morahan-Martin, The relationship between loneliness and internet use and abuse, in: M. V. Sari, N. Afiati, Studi komparasi nomophobia berdasarkan jenis kelamin pada mahasiswa, Jurnal Pemikiran dan Penelitian Psikologi, 24(2), 2019, pp. 141-148. DOI: 10.20885/psikologi.vol24.iss2.art4.

[25] L. Farooq et al., "Association between excessive use of mobile phones and insomnia among Pakistani 
teenagers cross-sectional study", American International Journal of Multidisciplinary Scientific Research, 5(4), 2019, pp. 10-15.

[26] M. Saiffullah, Hubungan penggunaan gadget terhadap pola tidur anak sekolah di upt sdn gadingrejo II pasuruan. Thesis, Universitas Airlangga, 2018.

[27] M. V. Sari, N. Afiati, Studi komparasi nomophobia berdasarkan jenis kelamin pada mahasiswa, Jurnal Pemikiran dan Penelitian Psikologi, 24(2), pp. 141-148. DOI: 10.20885/psikologi.vol24.iss2.art4.

[28] N. D. Hafni, "Nomophobia, penyakit masyarakat modern”, Jurnal Al-Hikmah, 6(2), 2018, pp. 41-50.

[29] Pavithra, S. Madhukumar, M. Murthy, "A study on nomophobia-mobile phones dependence, among students of medical college in Bangalore", National Journal of Community Medicine, 6(2), 2015, pp. 340344.

[30] Pavithra, S. Madhukumar, M. Murthy, A study on nomophobia-mobile phones dependence, among students of medical college in bangalore, in: D. A. Widyastuti, S. Muyana, Potret nomophobia (no mobile phone phobia) di kalangan remaja, 4(1), 2018, pp. 62-71, DOI: https://doi.org/10.26638/jfk.513.2099.

[31] Ramaita, Armaita, P. Vandelis, "Hubungan ketergantungan smartphone dengan kecemasan (nomophobia", Jurnal Kesehatan, 10(2), 2019, pp. 8993.

[32] R. D. Nasution, "Pengaruh perkembangan teknologi informasi komunikasi terhadap eksistensi budaya local", Jurnal Penelitian Komunikasi dan Opini Publik, 21(1), 2017, pp. 30-42.

[33] R. K. B. Philip et al., "A study on nomophobia and its correlation with sleeping difficulty and anxiety among medical students in a medical college in Telangana", International Journal of Community Medicine and Public Health, 6(5), 2019, pp. 2074-2076. DOI: http://dx.doi.org/10.18203/2394-6040.ijcmph 20191821.

[34] R. K. B. Philip et al., A study on nomophobia and its correlation with sleeping difficulty and anxiety among medical students in a medical college in Telangana, in: C. Yildirim, Exploring the dimensions of nomophobia: Developing and validating a questionnaire using mixed method research, Thesis, Iowa State University, 2014.

[35] R. Sutrisno, Faisal, F. Huda, Perbandingan kualitas tidur mahasiswa fakultas kedokteran universitas padjajaran yang menggunakan dan tidak menggunakan cahaya lampu saat tidur, Jurnal Sistem Kesehatan, 3(2), 2017, pp. 73-79.

[36] S. Hidayat, Mustikasari, "Kecanduan penggunaan smartphone dan kualitas tidur pada mahasiswa rik ui, 2014.

[37] S. K. Adams, T. S. Kisler, "Sleep quality as a mediator between technology-related sleep quality, depression, and anxiety", Cyberpsychology, Behaviour, and Social Networking, 16(1), 2013, pp. 25-30. DOI: 10.1089/cyber.2012.0157.

[38] V. K. Chattu et al., "The global problem of insufficient sleep and its serious public health implications", Healthcare, 7(1), 2019, pp. 1-16. DOI: 10.3390/healthcare7010001 